\title{
Geology, geochemistry and ore characteristics of the Jordanian phosphates
}

\author{
Ziad S. H. Abu-Hamatteh \\ Water Resources and Environmental M anagement D epartment, \\ Faculty of Agricultural Technology, AI-Balqa' A pplied U niversity, \\ Al-Salt, Jordan
}

\begin{abstract}
Jordan is situated on the northwestern side of the Arabian Plate, along the eastern flank of the ancient Tethys Ocean on the western side of the Dead Sea Transform. The country hosts huge phosphate deposits. The deposits at Eshidiya are comprised of overburden, four phosphate beds (A0, $\mathrm{Al}, \mathrm{A} 2$ and $\mathrm{A} 3$ ), a coquina/marl waste bed, and two silicified phosphate chert interwaste beds. Eshidiya ore beds are treated separately through beneficiation and upgrading, as they produce products of different grade; they are subdivided into three classes. A 65\% TCP (tricalcium phosphate) sub-commercial product is also produced. The detrimental impurities are considered to be among the lowest in the world. Chemical analyses of major oxides, organic matter and some traces in the product, which indicate almost similar chemical signature, are discussed herein.
\end{abstract}

Key words: phosphate, geochemistry, TCP (tricalcium phosphate), Jordan

\section{Introduction}

Jordan has enormous resources of phosphate ores with high quality $\mathrm{P}_{2} \mathrm{O}_{5}$ content, which encouraged the country to develop four operating mines at different locations in middle of Jordan, and to build up its own phosphate fertilizer complex at Aqaba. Phosphate-bearing horizons in Jordan occur at varying depth and cover about $60 \%$ of the total area of the country (Fig. 1- JPMC 1991) and comprise about 1 billion tons of resources. Jordan, with its Al-Hassa Mine (3.5 million tons), Al-Abiad Mine ( 2.5 million tons) and Eshidiya Mine (3.25 million tons), has the present design capacity to produce 9.25 million tons of

Address: $\quad$ Z. S. H. Abu-Hamatteh: Al-Balqa' Applied University, P.O. Box: 7064 (19117) Al-Salt-Jordan, e-mail: hamatteh@bau.edu.jo, drabuhamatteh@yahoo.com

Received: April 20, 2007, accepted: September 16, 2007 

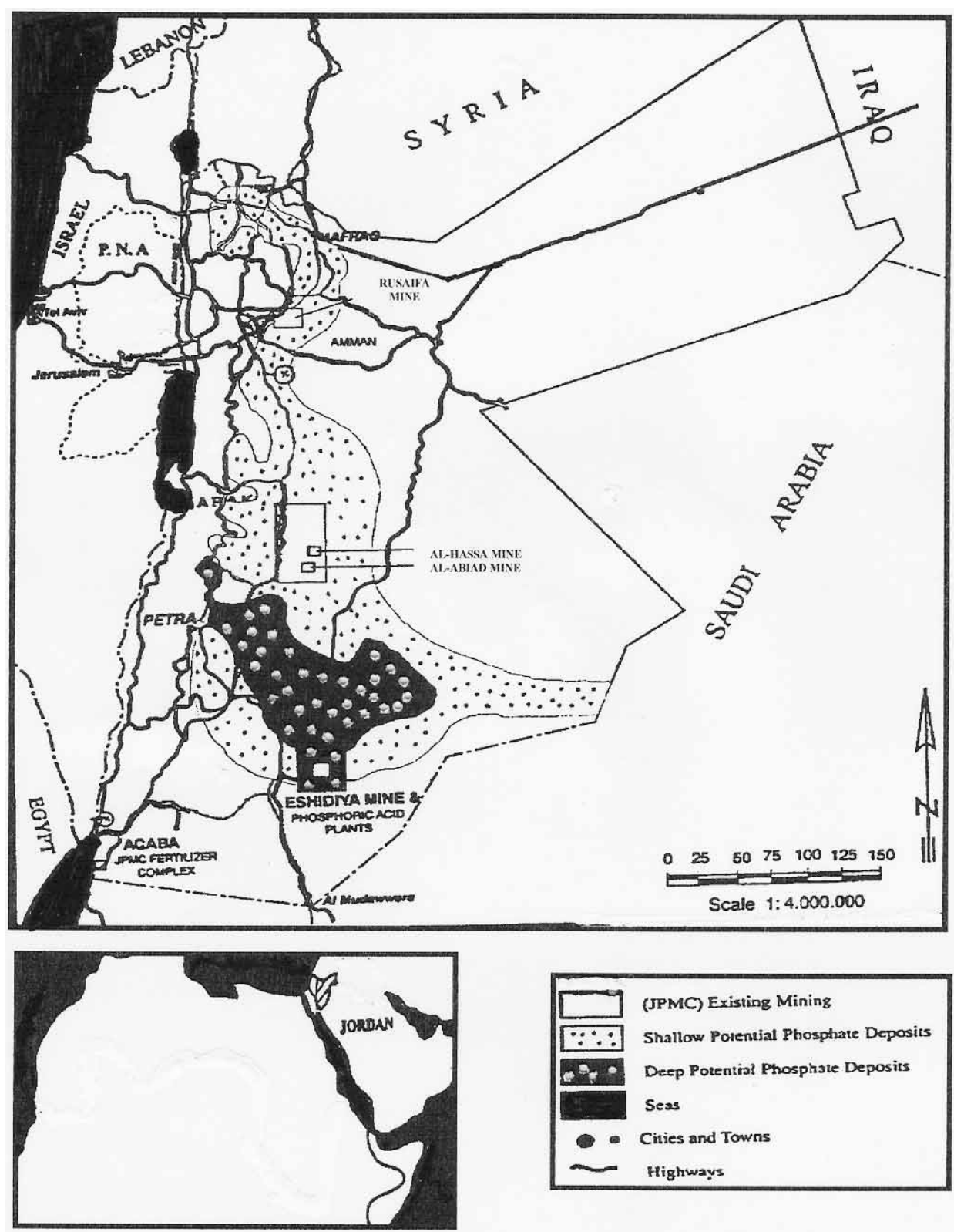

Fig. 1

Location map of phosphate deposits in Jordan, after JPMC 1991 
phosphate on an annual basis (JPMC 1999). In 1997, phosphate rock production in Jordan was about 5.8 million tons, which puts it in the 6th place behind the United States, China, Morocco, the former Soviet Union and Tunisia. The anticipated expansion of Eshidiya to 7.45 million tons improved Jordan's production globally to 5th place.

Three types are beneficiated and treated simultaneously at Eshidiya: (i) Al ore requires simple scrubbing, screening and desliming to produce an acceptable product when mined from under the coquina bed; (ii) A2 ore is basically a direct shipping high-grade bed that requires only dry screening and dedusting to produce an acceptable product and (iii) A3 ore must be scrubbed, screened and deslimed in the same manner as for $A 1$ ore, in addition to flotation for removal of fine silica, in order to make an acceptable product. The present study aims at examining the chemistry and ore characteristics of the Jordanian phosphates, in order to overcome the difficulties associated with the overall beneficiation process.

\section{Geology, geochemistry and ore characteristics}

Geologic setting

The oldest known formation of Jordan, the Precambrian Aqaba Granite Complex, crops out in its southwestern part (Bender 1968). Since the Precambrian the granitic shield is predominantly a land surface ringed by seas receiving sediment from the land. Generally, Jordanian tectonic history is divided into three phases: the Gondwana, Syrian Arc and Rift phases (Dewey et al. 1973). During the Gondwana phase (Cambrian-Early Cretaceous), Jordan was located near the northern margin of the Gondwana paleocontinent. Tectonically the area was relatively stable and the sedimentation was predominantly of continental type, interspersed with rather minor but widespread marine incursions. However, the Lower Paleozoic rocks of Cambrian, Ordovician and Silurian age are crop out in southern Jordan and on the eastern side of the Dead Sea-Jordan Rift Valley. Several wells have encountered Upper Carboniferous and Permian rocks of the pre-rift sequence, indicating a variety of depositional environments, from continental clastic to shallow marine carbonate. In fact this general sedimentation pattern continued into the Triassic and Early Jurassic, but became increasingly more aquatic. The shoreline position from Triassic to Late Cretaceous remained largely unchanged across central Jordan, with the open sea lying to the northwest.

It has been noticed that during the Late Cretaceous, subduction of the $\mathrm{NeO}$ Tethyan oceanic lithosphere was initiated from the north, whereas the resulting compression along the southern margin of $\mathrm{Neo}$-Tethys is indicated within locally obducted ophiolites and folding in the Syrian Arc trend (Bender 1974; BenAvraham and Grasso 1991). The Syrian Arc shows a sigmoidal trend, extending from the northern Sinai northward into Syria (Fig. 2), following the trend of the 
Late Cretaceous continental margin. However, extension within the Arabian Plate during the Late Cretaceous (Bender 1974; Lovelock 1984) caused a series of northwest-trending basins, such as the Al-Azraq and Wadi Sirhan Basins (Fig. 3 Bender 1974). At later stages, strike-slip faulting in the Neogene modified the

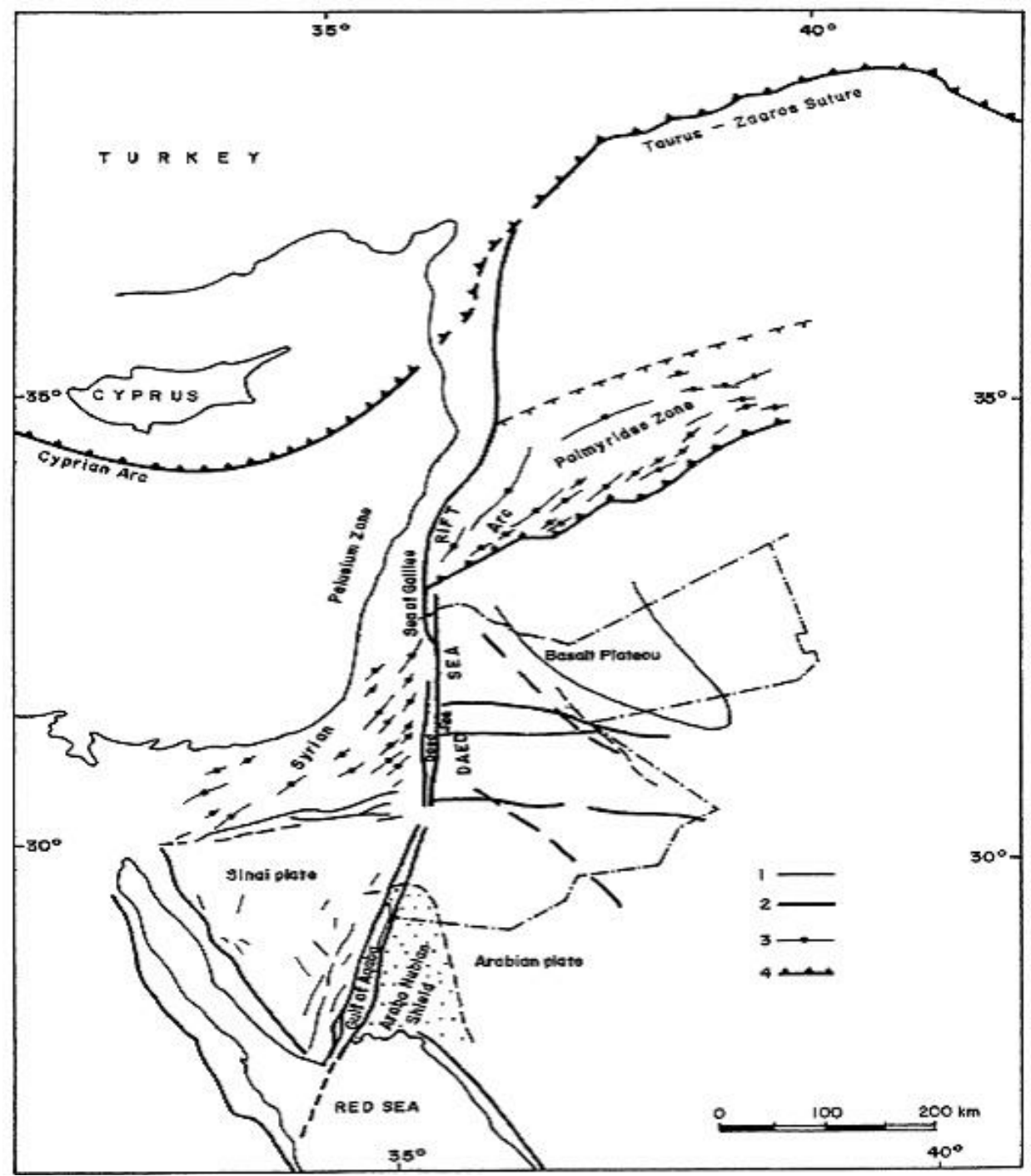

Fig. 2

Generalized tectonic setting of the Middle East showing the Arabian Plate, the Sinai Sub-plate, the Dead Sea Transform (including the Gulf of Aqaba, the Dead Sea and the Sea of Galilee) and Palmyrides zone. 1. Faults; 2. Main Faults; 3. Fold Axes; 4. Main Thrust Fronts (modified after Bender 1974; Ben-Avraham and Grasso 1991) 


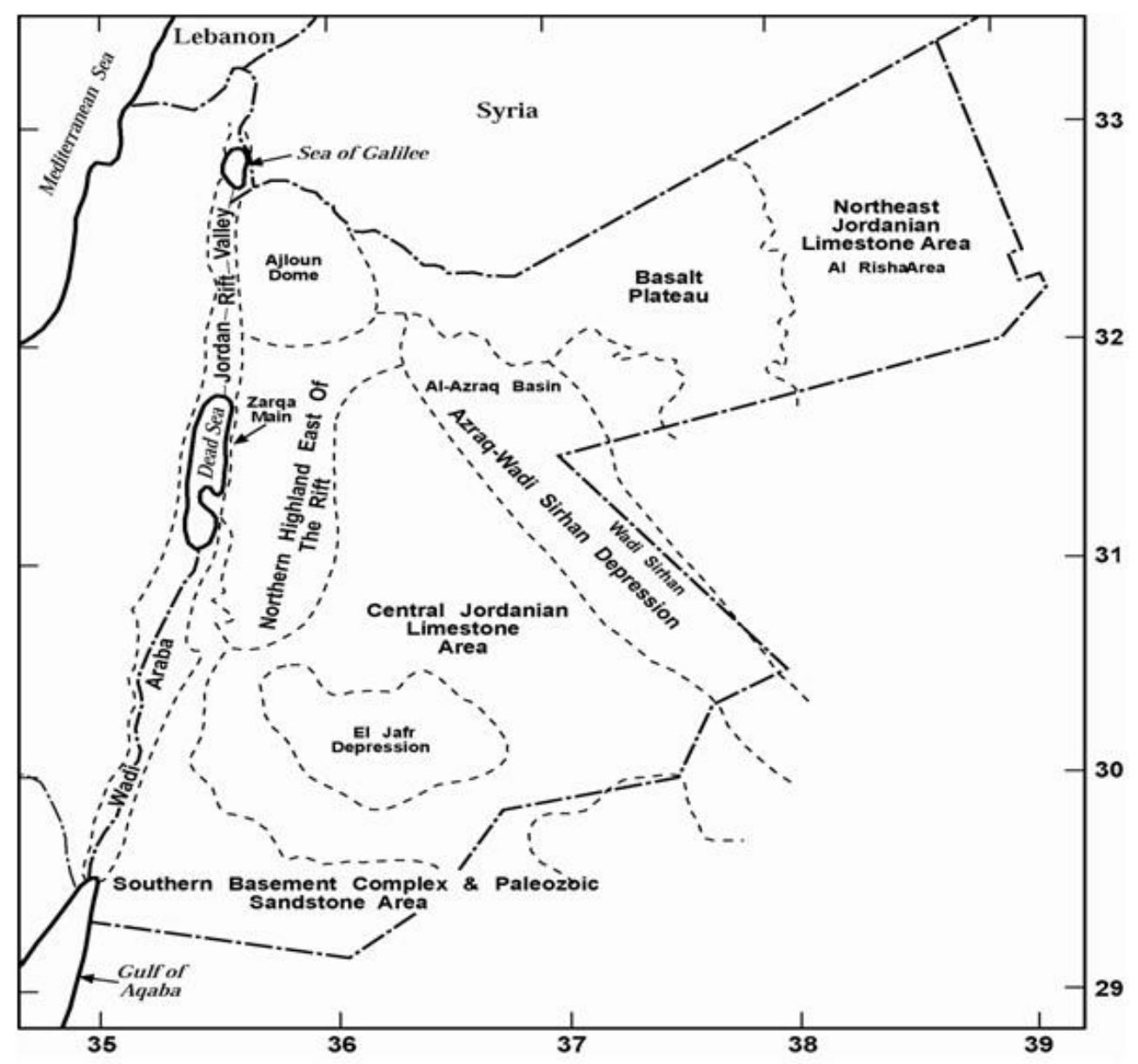

Fig. 3

Geologic-physiographic provinces of Jordan after Bender (1974)

overall configuration and structural style of the Al-Azraq and Wadi Sirhan Basins, and then offset and modified the fold geometry of the Syrian Arc trend. Different transgressions from the northwest to the southeast were repeated several times during the Mesozoic. Moreover, between the middle Jurassic and Early Cretaceous volcanism was active in the western part of Jordan. Mafic as well as felsic dykes and sills occurred in the Wadi Araba region, cutting across the Mesozoic sedimentary rocks (Bender 1974).

During the Late Oligocene-Early Miocene, the left lateral movement along the Dead Sea-Jordan Rift Valley was initiated, along with the deposition of coarse, lenticular, unsorted conglomerates, which begin to appear in the section overlying Late Cretaceous or Tertiary units in the eastern Wadi Araba area. However, 
they show an unconformable relationship in several localities, indicating uplift and probably tectonic activity (Bender 1974). Therefore, the regional fault system consists of a series of three major west-stepping, en-echelon faults, with welldefined pull-apart basins having formed at each of the major offshoots, i.e. the Gulf of Aqaba, Dead Sea Basin and Sea of Galilee Basin (Figs 2 and 3).

The deposits of Quaternary age in Jordan reflect continuous uplift and retreat of the marine environment. An extensive mafic volcanic and shallow intrusive activity occurs in the form of localized flows and plugs. Plateau flood basalts with primitive chemistry appear to reflect a rapid propagation of fractures into the mantle, followed by rapid extrusion (Barberi et al. 1979). Based on the geologic history described above and other geologic, paleogeographic and stratigraphic evidence, the territory of Jordan can be subdivided into seven major geologicphysiographic provinces, as in Figure 3.

The phosphate formations in the Upper Cretaceous and Eocene levels cover about $60 \%$ of the total area of Jordan. The phosphate formations of the Upper Cretaceous lie near the surface in the central part of the country, covering a wide belt. The Al-Hassa and Al-Abiad phosphate deposits are found in two horizons, but these deposits have a lenticular shape, in contrast to the Rusaifa and Eshidiya areas, where the deposits occur in continuous beds.

The Eshidiya phosphate deposits in central Jordan lie within the Upper Cretaceous limestone plateau (Bender 1974). They comprise about $125 \mathrm{sq} . \mathrm{km}$ and are estimated to be 65 million years old (Upper Cretaceous) (Abed 1985; Bender 1974; Quennell 1951). The deposits are sedimentary in nature (Hopper 1976; Moudgil and Chanchani 1985) and are thought to have been formed in the following sequence; (i) upwelling of cold, phosphaterich seawater into warm shallow waters, (ii) growth of algae, plants, fish, and mammals due to the rich nutrients, (iii) phosphatization of calcareous, siliceous and clay sediments on the shallow sea floor, along with deposition of phosphaterich teeth and bones from animals, (iv) reworking of the phosphate sediments by current or wave action and finally, ( $v$ ) after the seawater receded, weathering of the phosphate sediments, with rains that leached the softer limestone and left behind the quartz and less soluble phosphates (Sheldon 1964; Beall and Merritt 1966; Gieseke 1985).

The deposits at Eshidiya are made up of overburden, four phosphate beds (A0, Al, A2 and A3), a coquina/marl waste bed, and two silicified phosphate/chert interwaste beds. The lithology and stratigraphic column (Bender 1974) is shown in Figure 4.

\section{O re characteristics}

Jordanian phosphate rock is known for its softness, grindability, porosity and reactivity. The high reactivity reduces reaction time and gives a higher yield. In sedimentary deposits such as those found in Jordan, the ore generally consists of phosphate particles ranging from $20 \mathrm{~mm}$ to 50 microns in size, sand and clay 
Geology, geochemistry and ore characteristics of the Jordanian phosphates 289

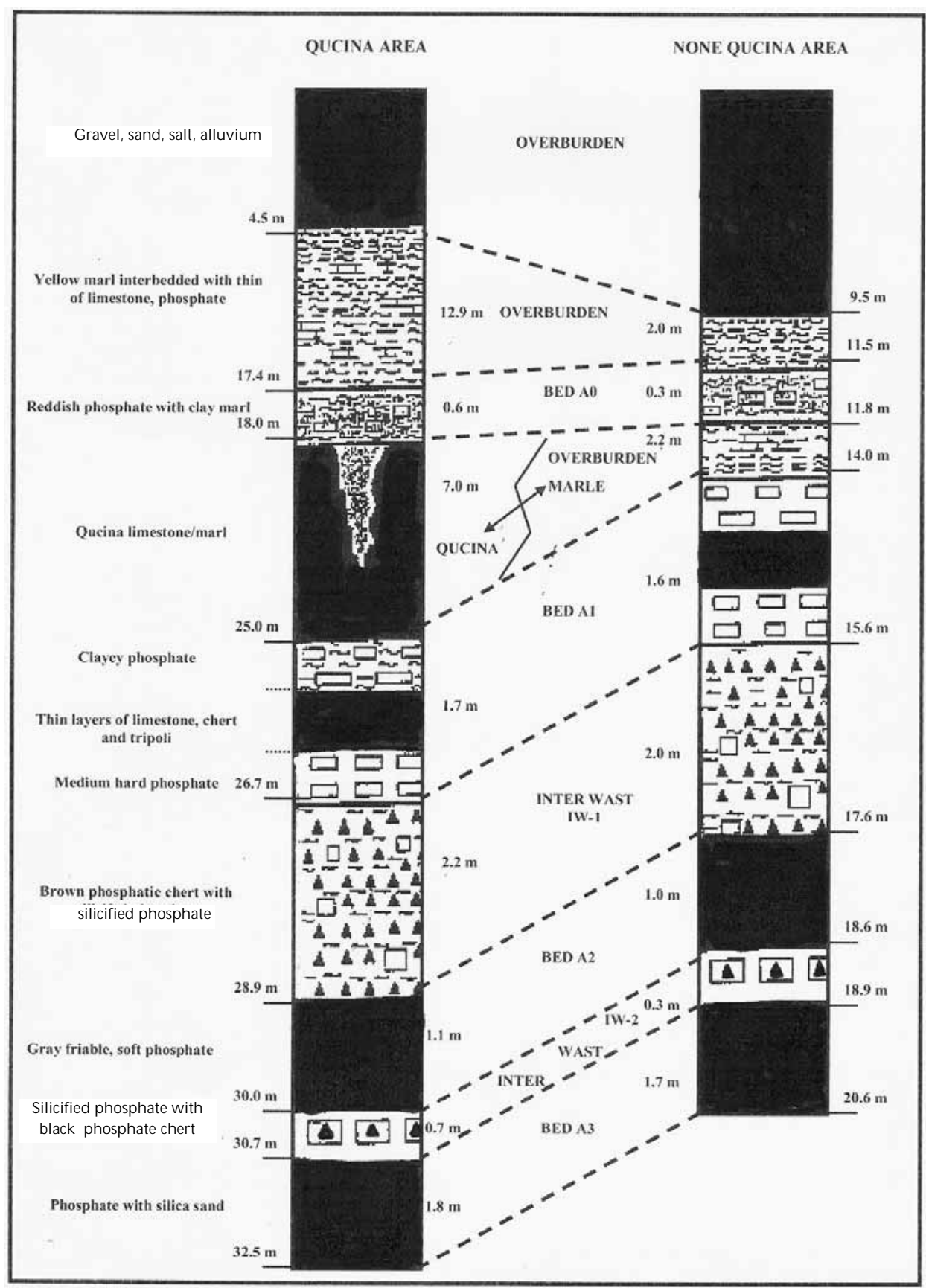

Fig. 4

Stratigraphic column of Eshidiya area 
ranging from one $\mathrm{mm}$ to less than two microns. Clay can be present in large lumps, but scrubbing and wetting with water will generally reduce it to its natural grain size of less than two microns. The ore beds generally rest on hard limestone and are overlain by overburden sand. Eshidiya ore characteristics are given in Table 1.

Table 1

Ore characteristics of Eshidiya phosphates compared to Florida and Canada Ores

\begin{tabular}{|l|c|c|c|}
\hline Characteristics & $\begin{array}{c}\text { Sedimentary } \\
\text { Eshidiya }\end{array}$ & $\begin{array}{c}\text { Sedimentary } \\
\text { Florida }\end{array}$ & $\begin{array}{c}\text { Igneous } \\
\text { Canada }\end{array}$ \\
\hline Tons product/hectare mined & 40,000 & $12,000-18,000$ & - \\
\hline Overburden/matrix & 5.0 & $1.5-2.0$ & - \\
\hline Ore $\mathrm{m}^{3}$ /ton product & 2.5 & $2.5-5.0$ & $1.5-3.0$ \\
\hline Float feed \% TCP & $40-65$ & $10-25$ & $40-60$ \\
\hline $1 \mathrm{~mm}$ sub com./concentrate tones & 0.05 & $1.2-1.7$ & 0 \\
\hline Product \% TCP (tricalcium phosphate) & $65-78$ & $62-74$ & $83-88$ \\
\hline Detrimental impurities $\left(\mathrm{Fe}_{2} \mathrm{O}_{3}+\mathrm{Al}_{2} \mathrm{O}_{3}+\mathrm{MgO}\right) \%$ & $0.6-0$ & $2.4-2.8$ & $2.5-2.4$ \\
\hline
\end{tabular}

In general, the ore body at Eshidiya (40,000 tons/hectare) is richer than those in the United States (12,000-18,000 tons /hectare) but 2.5 to 3.5 times more overburden must be stripped off to reach the ore zone (Ranney 1980; Zhang 1993; Donald 1994; Elliott 1994; Wills 1997). Feed grades at Eshidiya are equal to those in Canada and about four times higher than in the United States. Product quality at Eshidiya is similar to that in the United States, but much less than the quality in Canada, since the Canadian deposits are igneous in origin and the phosphate is present as pure apatite. Detrimental product impurities $\left(\mathrm{Fe}_{2} \mathrm{O}_{3}, \mathrm{Al}_{2} \mathrm{O}_{3}\right.$ and $\mathrm{MgO}$ ) at Eshidiya are some of the lowest in the world (Table 1). Due to the low impurities, the Jordanian phosphate rock provides a high yield of high-purity phosphoric acid and is thus available for the chemical industry without pretreatment, as in producing Sodium Tripoli Phosphate and other chemical products.

Mirror glass is an effective way to judge the amount of silica present in a final concentrate. Although this method does not provide as much information as a microscope, generally it can still be used by an experienced operator to estimate the true silica in concentrates within $1.0 \%$. When viewed through the mirror the silica will sparkle, while the phosphate will remain dark. The procedure is simply reversed for estimates of silica in concentrates, as the silica will sparkle and be the minor constituent. 
Geochemistry

Several phosphate samples with different TCP (trical cium phosphate) contents were collected from the Al-Hassa, Al-Abiad and Eshidiya mines. The chemical analyses are presented in Table 2, showing the representative average chemical analyses (range \% and ppm). The samples were analyzed at the Research Center of Rusaifa Mine using X-Ray Quantometer (JPMC 1991).

Trace element evaluation indicates a high concentration of $\mathrm{Cr}(70-100 \mathrm{ppm})$ in the Al-Hassa and Al-Abiad mines, dropping to 50-60 ppm in the case of the Eshidiya phosphate. The overall trace element concentration is lower in the Eshidiya phosphate compared with Al-Hassa and Al-Abiad, except for Cd with 4 ppm as a lower limit. The chemical analyses (Table 2) indicate almost similar major oxides and trace element concentrations for the various TCP grades considered.

The low chlorine content in the Jordanian phosphate rock, ranging from 0.02 to 0.08 , and optimum fluorine to silica reaction (ranging from 3.5 to 4.0 ) means minimum corrosion (Table 2). Low $\mathrm{R}_{2} \mathrm{O}_{3}\left(\mathrm{Fe}_{2} \mathrm{O}_{3}, \mathrm{Al}_{2} \mathrm{O}_{3}\right)$ (less than $0.5 \%$ ) minimizes sludge formation while standing and during transportation of both the diluted and the concentrated acids. Jordanian phosphate fines of all grades are soluble in citric acid (ranging from $28 \%$ to $34 \%$ ), considered to be the highest solubility compared to other phosphate rocks. Phosphoric acid is generally produced by reacting phosphate rock with sulfuric acid. Al-Hassa and Al-Abiad's low chlorine phosphate are mostly of $70-72 \%, 71-73 \%, 72-74 \%$ and $73-75 \%$ TCP grades. Eshidiya currently produces $73-75 \%$ TCP.

Table 3 represents the screen analyses (in $\mathrm{mm}$ ) of the corresponding phosphate samples with different TCP contents, collected from the three Jordanian mines and presented in Table 2. Screen analysis shows similar characteristics of 69/70\%, $70 / 72 \%$ (standard) and 70/72 (low chlorine) TCP grade samples colleted from the Al-Hassa and Al-Abiad mines. However, $-270 \mathrm{~mm}$ mesh is 1.5-6.0 in the case of $69 / 70 \%$ TCP grade. On one hand, 71/73, 72/74 and 73/75-grade samples of AlHassa and Al-Abiad indicate more or less similar features. On the other hand 73/75-grade shows higher values of +48 and +100 mesh, as 30.0-40.0 and 22.031.0 respectively. The $73 / 75$ and $75 / 77$ TCP grade samples of Eshidiya are identical (Table 3).

\section{$M$ ining of phosphate}

Phosphate rock has been exploited in Jordan since the late thirties of the last century, and mining began systematically in 1953 in the Rusaifa area, about $15 \mathrm{~km}$ northeast of Amman. Production expanded gradually and started in 1962 from the Al-Hassa mine, which is located about $136 \mathrm{~km}$ south of Amman and about 200 $\mathrm{km}$ north of the port of Aqaba. The expansion of the mining activities continued both by increasing the production from mines and exploiting new phosphate deposits; thus production from the Al-Abiad mine, situated about $20 \mathrm{~km}$ north of 


\begin{tabular}{|c|c|c|c|c|c|c|c|c|c|c|c|c|c|c|c|c|c|c|c|c|}
\hline 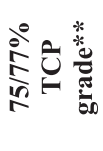 & $\mid \begin{array}{c}\dot{0} \\
\dot{d} \\
\tilde{p} \\
\dot{j} \\
\dot{m}\end{array}$ & $\mid \begin{array}{c}0 \\
i \\
i \\
0 \\
\dot{1} \\
\text { in }\end{array}$ & $\begin{array}{l}\stackrel{+}{+} \\
\text { i } \\
\text { i }\end{array}$ & $\begin{array}{l}\dot{O} \\
\dot{J} \\
\dot{r} \\
\dot{m}\end{array}$ & $\begin{array}{l}0 \\
\dot{+} \\
\infty \\
\dot{m}\end{array}$ & \begin{tabular}{|l}
0 \\
0 \\
0 \\
0 \\
0 \\
0 \\
0
\end{tabular} & $\mid \begin{array}{l}0 \\
0 \\
0 \\
0 \\
0 \\
0 \\
0\end{array}$ & 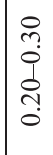 & 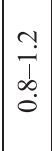 & $\begin{array}{l}0 \\
0 \\
0 \\
0 \\
0\end{array}$ & $\begin{array}{l}\stackrel{8}{0} \\
\dot{0} \\
\tilde{o} \\
\dot{0}\end{array}$ & 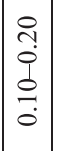 & $\mid \begin{array}{l}n \\
\mathfrak{y} \\
0 \\
\vdots \\
\grave{1} \\
0\end{array}$ & $\mid \begin{array}{c}n \\
0 \\
0 \\
0 \\
0 \\
0\end{array}$ & $\mid \begin{array}{c}\tilde{1} \\
\tilde{1} \\
\infty \\
- \\
-\end{array}$ & \begin{tabular}{l|l}
0 & \\
0 & \\
$o$ &
\end{tabular} & $\begin{array}{l}8 \\
0 \\
9\end{array}$ & of & $\begin{array}{l}8 \\
0 \\
0 \\
\text { in }\end{array}$ & f \\
\hline 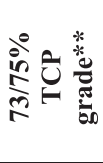 & $\mid \begin{array}{c}m \\
\dot{p} \\
\dot{f} \\
\dot{m} \\
\tilde{m}\end{array}$ & $\begin{array}{l}n \\
n \\
5 \\
0 \\
\dot{0} \\
n\end{array}$ & $\begin{array}{l}0 \\
\dot{j} \\
0 \\
\dot{m}\end{array}$ & $\begin{array}{l}\dot{P} \\
\dot{j} \\
\dot{m}\end{array}$ & $\begin{array}{l}0 \\
\dot{+} \\
n \\
m\end{array}$ & $\begin{array}{l}0 \\
0 \\
0 \\
0 \\
0 \\
0 \\
0\end{array}$ & $\mid \begin{array}{l}0 \\
0 \\
0 \\
n \\
0 \\
0 \\
0\end{array}$ & 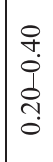 & $\mid \begin{array}{c}n \\
\dot{1} \\
\stackrel{0}{-}\end{array}$ & $\begin{array}{l}0 \\
0 \\
\dot{j} \\
\dot{0}\end{array}$ & $\begin{array}{l}\text { t } \\
\text { d } \\
0 \\
\text { dे } \\
0 \\
0\end{array}$ & $\mid \begin{array}{c}0 \\
i \\
0 \\
0 \\
0 \\
0 \\
0\end{array}$ & 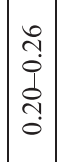 & $\mid \begin{array}{l}n \\
0 \\
0 \\
0 \\
0 \\
0\end{array}$ & $\left|\begin{array}{c}\tilde{N} \\
\tilde{1} \\
\infty \\
-\end{array}\right|$ & \begin{tabular}{l|l}
0 & \\
0 & \\
$o$ &
\end{tabular} & $\begin{array}{l}8 \\
0 \\
9\end{array}$ & $q$ & $\begin{array}{l}0 \\
\vdots \\
0 \\
n\end{array}$ & f \\
\hline 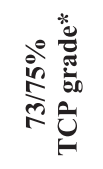 & $\begin{array}{c}m \\
\tilde{j} \\
\tilde{j} \\
\tilde{m} \\
\tilde{m}\end{array}$ & $\begin{array}{l}0 \\
\dot{n} \\
0 \\
\text { in } \\
\text { n }\end{array}$ & $\begin{array}{l}n \\
i \\
n \\
i\end{array}$ & $\begin{array}{l}0 \\
\dot{j} \\
\dot{b} \\
\dot{+}\end{array}$ & $\begin{array}{l}a \\
\dot{b} \\
\dot{b} \\
\dot{m}\end{array}$ & \begin{tabular}{|l}
1 \\
0 \\
0 \\
0 \\
0 \\
0 \\
0
\end{tabular} & $\left|\begin{array}{c}\stackrel{1}{1} \\
0 \\
b \\
0 \\
0\end{array}\right|$ & 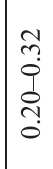 & 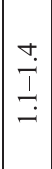 & $\begin{array}{l}0 \\
0 \\
+ \\
0\end{array}$ & $\begin{array}{l}\text { t. } \\
\dot{0} \\
\text { Iे } \\
0 \\
0\end{array}$ & $\mid$\begin{tabular}{l}
$q$ \\
\multirow{0}{0}{} \\
0 \\
\\
0
\end{tabular} & 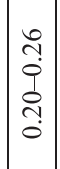 & 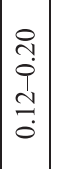 & $\mid \begin{array}{c}\tilde{D} \\
\tilde{D} \\
\stackrel{\infty}{-}\end{array}$ & $\begin{array}{ll}\infty \\
\infty \\
⿱ \\
2 & \\
\end{array}$ & $\begin{array}{l}0 \\
i \\
0 \\
n\end{array}$ & $n$ & $\begin{array}{l}8 \\
\frac{1}{2} \\
?\end{array}$ & in \\
\hline 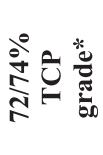 & $\begin{array}{l}a \\
\dot{m} \\
\hat{i} \\
\hat{j} \\
\tilde{n}\end{array}$ & 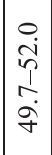 & $\begin{array}{l}\text { : } \\
\text { ț } \\
\text { i. }\end{array}$ & $\begin{array}{l}0 \\
\dot{p} \\
\dot{1} \\
\dot{+}\end{array}$ & $\begin{array}{l}a \\
\dot{p} \\
n \\
\dot{m}\end{array}$ & $\begin{array}{l}\infty \\
0 \\
0 \\
0 \\
0 \\
0\end{array}$ & 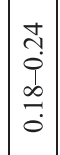 & $\begin{array}{l}\infty \\
0 \\
0 \\
0 \\
0 \\
0 \\
0 \\
0 \\
0\end{array}$ & 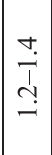 & $\begin{array}{l}0 \\
0 \\
\vdots \\
0 \\
0\end{array}$ & $\begin{array}{l}\text { t. } \\
0 \\
\vdots \\
0 \\
0 \\
0\end{array}$ & $\mid \begin{array}{l}0 \\
9 \\
0 \\
0 \\
\hat{a} \\
0\end{array}$ & $\mid$ & 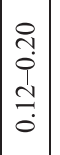 & $\begin{array}{c}\tilde{N} \\
\tilde{D} \\
\infty \\
- \\
-\end{array}$ & \begin{tabular}{l|l}
$\infty$ & \\
0 & \\
$\triangleright$ &
\end{tabular} & $\begin{array}{l}0 \\
1 \\
i \\
n\end{array}$ & $n$ & $\begin{array}{l}8 \\
\frac{1}{2} \\
?\end{array}$ & in \\
\hline 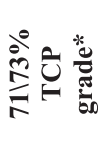 & $\begin{array}{c}\vec{j} \\
\dot{m} \\
\tilde{n} \\
\dot{m} \\
\tilde{m}\end{array}$ & $\begin{array}{l}0 \\
\dot{1} \\
\vdots \\
\dot{g} \\
\dot{q}\end{array}$ & 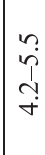 & $\begin{array}{l}n \\
n \\
b \\
0 \\
\dot{q}\end{array}$ & $\begin{array}{l}a \\
\dot{b} \\
\dot{b} \\
\dot{m}\end{array}$ & $\begin{array}{l}\infty \\
0 \\
0 \\
\dot{0} \\
0 \\
0\end{array}$ & $\mid \begin{array}{c}0 \\
\tilde{0} \\
0 \\
\tilde{̣} \\
0 \\
0\end{array}$ & $\begin{array}{l}o \\
q \\
0 \\
0 \\
0 \\
0 \\
0\end{array}$ & 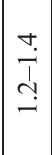 & $\begin{array}{l}0 \\
\dot{0} \\
\vdots \\
0\end{array}$ & 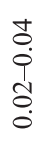 & $\mid \begin{array}{l}0 \\
⿱ \\
0 \\
0 \\
0 \\
0 \\
0\end{array}$ & \begin{tabular}{|l|}
$\infty$ \\
$\stackrel{1}{0}$ \\
0 \\
$\vdots$ \\
$\grave{1}$ \\
0
\end{tabular} & $\begin{array}{c}\tilde{I} \\
0 \\
\vdots \\
\beth \\
0 \\
0\end{array}$ & $\mid \begin{array}{c}\tilde{D} \\
\tilde{D} \\
\infty \\
- \\
-\end{array}$ & \begin{tabular}{l|l}
0 & \\
0 & \\
0 & \\
2 &
\end{tabular} & $\begin{array}{l}0 \\
1 \\
i \\
n\end{array}$ & $m$ & $\begin{array}{l}8 \\
\frac{1}{2} \\
2\end{array}$ & in \\
\hline 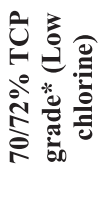 & $\begin{array}{c}0 \\
\dot{j} \\
\dot{j} \\
\dot{j} \\
\tilde{m}\end{array}$ & $\begin{array}{l}n \\
0 \\
0 \\
0 \\
\dot{g} \\
\dot{q}\end{array}$ & $\begin{array}{l}n \\
n \\
n \\
\sigma \\
\sigma\end{array}$ & \begin{tabular}{|l|}
$n$ \\
0 \\
0 \\
0 \\
$\dot{\gamma}$
\end{tabular} & $\begin{array}{l}\infty \\
\dot{p} \\
n \\
n \\
n\end{array}$ & $\begin{array}{l}\infty \\
0 \\
0 \\
0 \\
0 \\
0\end{array}$ & $\left|\begin{array}{c}n \\
0 \\
0 \\
n \\
n \\
0 \\
0\end{array}\right|$ & $\begin{array}{l}o \\
0 \\
0 \\
0 \\
n \\
0 \\
0\end{array}$ & $\begin{array}{l}\stackrel{+}{\Xi} \\
\stackrel{I}{I} \\
=\end{array}$ & $\begin{array}{l}0 \\
0 \\
0 \\
0 \\
0\end{array}$ & 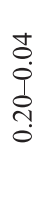 & $\mid \begin{array}{l}n \\
y \\
0 \\
0 \\
0 \\
0 \\
0\end{array}$ & 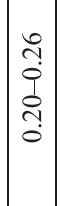 & 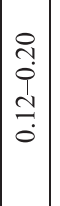 & $\mid \begin{array}{c}\tilde{1} \\
\tilde{i} \\
\infty \\
- \\
-1\end{array}$ & \begin{tabular}{l|l}
$\infty$ \\
0 \\
$⿱$ \\
2 &
\end{tabular} & $\begin{array}{l}i \\
i \\
i \\
\text { n. }\end{array}$ & $m$ & & in \\
\hline 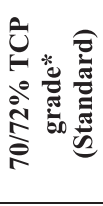 & $\begin{array}{c}0 \\
\dot{j} \\
\hat{j} \\
\dot{j} \\
\tilde{m}\end{array}$ & $\begin{array}{l}0 \\
0 \\
0 \\
0 \\
0 \\
\dot{q} \\
\dot{q}\end{array}$ & 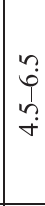 & $\begin{array}{l}0 \\
\dot{b} \\
0 \\
\dot{+}\end{array}$ & $\begin{array}{l}\infty \\
\dot{p} \\
n \\
n \\
n\end{array}$ & \begin{tabular}{l}
$n$ \\
\multirow{1}{*}{} \\
0 \\
$\infty$ \\
0 \\
0 \\
0
\end{tabular} & $\left|\begin{array}{c}n \\
0 \\
0 \\
0 \\
n \\
0 \\
0\end{array}\right|$ & $\begin{array}{l}9 \\
0 \\
0 \\
1 \\
\\
0\end{array}$ & $\begin{array}{c}\stackrel{+}{+} \\
\stackrel{+}{I} \\
\stackrel{-}{-}\end{array}$ & $\begin{array}{l}0 \\
\dot{0} \\
\dot{0} \\
0\end{array}$ & 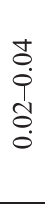 & $\mid$\begin{tabular}{|}
$\mid$ \\
$f$ \\
0 \\
0 \\
0 \\
0 \\
0 \\
\end{tabular} & 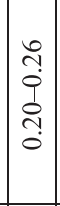 & $\left|\begin{array}{c}0 \\
0 \\
0 \\
i \\
0 \\
0\end{array}\right|$ & $\mid \begin{array}{c}\tilde{N} \\
\tilde{D} \\
\infty \\
- \\
-\end{array}$ & $\begin{array}{ll}0 & \\
\infty & \\
2 & \\
2 & \end{array}$ & $\begin{array}{l}2 \\
i \\
i \\
n\end{array}$ & $m$ & $\begin{array}{l}8 \\
\frac{1}{2} \\
2\end{array}$ & in \\
\hline 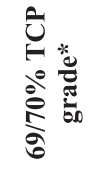 & $\mid \begin{array}{c}\vec{i} \\
\hat{d} \\
b \\
\vec{m}\end{array}$ & $\mid \begin{array}{l}n \\
0 \\
i \\
n \\
o \\
\alpha \\
\sigma\end{array}$ & $\begin{array}{l}\tilde{N} \\
0 \\
m \\
m \\
m\end{array}$ & $\begin{array}{l}n \\
n \\
n \\
n \\
+ \\
+\end{array}$ & $\begin{array}{l}\infty \\
\infty \\
n \\
n \\
n \\
c\end{array}$ & $\begin{array}{l}8 \\
0 \\
0 \\
0 \\
0 \\
0\end{array}$ & $\left|\begin{array}{l}2 \\
0 \\
0 \\
0 \\
0 \\
0 \\
0\end{array}\right|$ & 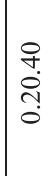 & $\begin{array}{l}n \\
I \\
I \\
-\end{array}$ & $\begin{array}{c}0 \\
0 \\
\vdots \\
m \\
0\end{array}$ & $\begin{array}{l}t \\
0 \\
0 \\
\vdots \\
0 \\
0 \\
0\end{array}$ & 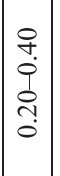 & $\mid \begin{array}{c}0 \\
0 \\
0 \\
0 \\
\grave{1} \\
0\end{array}$ & $\mid \begin{array}{c}n \\
\hat{1} \\
0 \\
\beth \\
0 \\
0\end{array}$ & $\mid \begin{array}{c}\tilde{a} \\
\tilde{D} \\
\stackrel{\infty}{-}\end{array}$ & \begin{tabular}{l|l}
$\otimes$ \\
0 \\
0
\end{tabular} & $\begin{array}{l}0 \\
1 \\
i \\
n\end{array}$ & $m$ & $\begin{array}{l}8 \\
0 \\
0 \\
2\end{array}$ & in \\
\hline 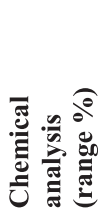 & |" & & a & $\mathcal{O}^{N}$ & | & $\bar{\tau}$ & 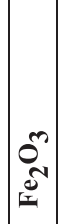 & & $\delta_{n}^{m}$ & 4 & 2 & $\begin{array}{l}0 \\
O_{2}^{+\infty} \\
\sum_{2}\end{array}$ & 号 & 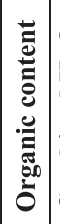 & 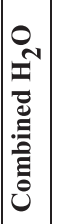 & : & 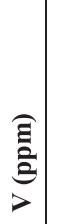 & 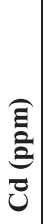 & 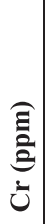 & $\begin{array}{l}\widehat{a} \\
\overline{0} \\
\bar{z} \\
y\end{array}$ \\
\hline
\end{tabular}


Geology, geochemistry and ore characteristics of the Jordanian phosphates 293

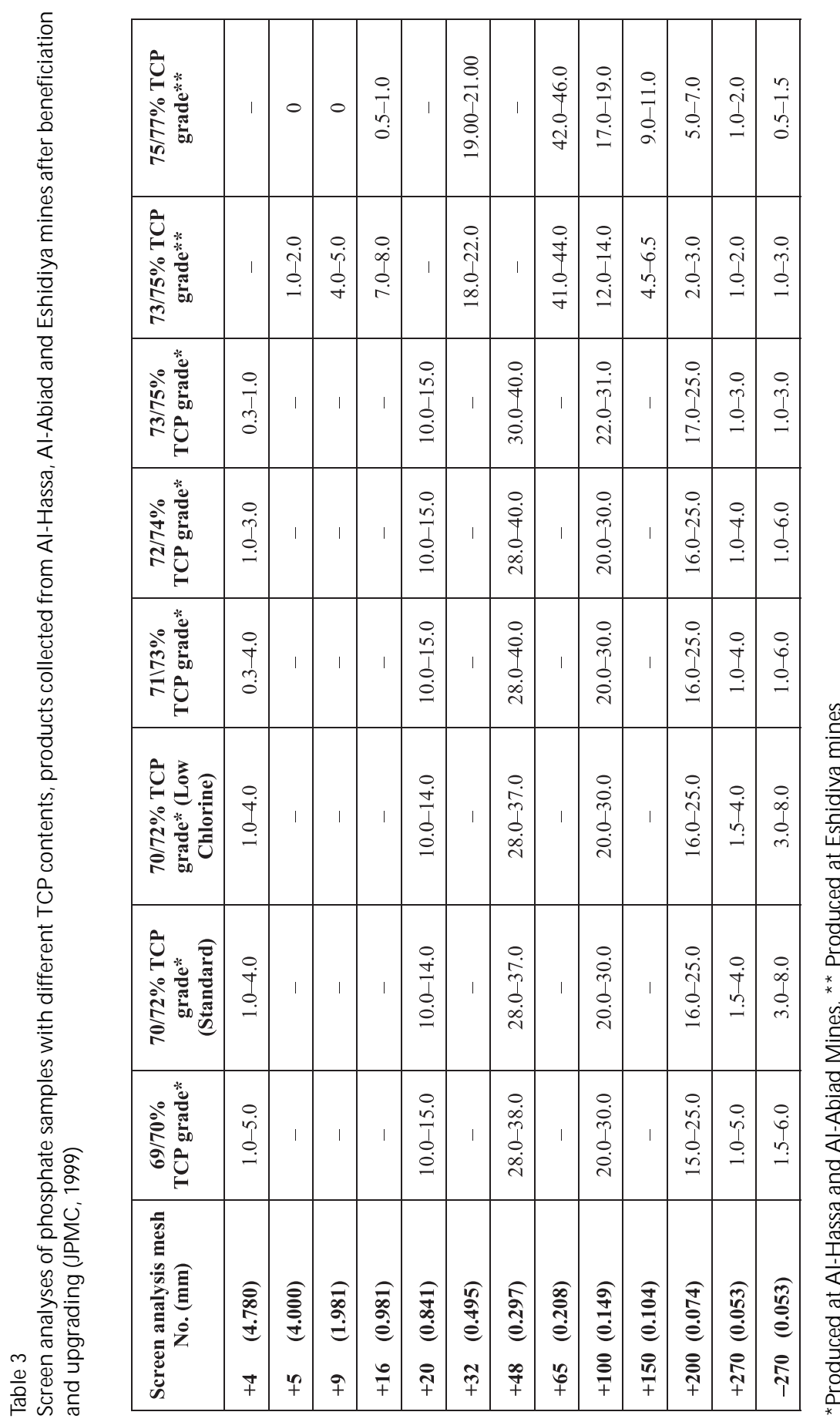


the Al-Hassa mine, began in 1979. Production at the Eshidiya mine started in 1988 and now exceeds 12 MTP (million tons phosphate). The latter will replace both the Al-Hassa and Al-Abiad mines. In Florida, the overburden is generally 10-15 meters thick, consisting of fine sand, usually dug with a dragline and cast in spoil piles (Hopper 1976). The one to four m-thick clayey ore is dug with a dragline and dropped into a pit where it is slurried with high-pressure water and pumped into the plant. In North Carolina (United States) the overburden is removed with a Bucket Wheel Excavator, since the overburden exceeds 20 meters (Gieseke 1985).

The reserves at Eshidiya consist of two ore bodies, called the eastern and western ore bodies. At present, mining is carried out in the western and the eastern pits within the western ore body. One of the pits is in the coquina area, while the other is in the non-coquina area. At Eshidiya, the overburden is drilled and blasted, and then removed with draglines. Overburden removal is down to the top of layer Al. The phosphate ore layers Al, A2 and A3 and the two inner waste layers are selectively removed with a system of shovels and trucks. It is important to note that the ore beds are kept separate through beneficiation, since they grade upward in different manner and produce products of different grade, as described in the introduction of the present paper. The products are classified as: (1) Al Ore: $68-70 \%$ product, (2) A2 Ore: 73-75\% TCP product and (3) A3 Ore: $75-77 \%$ TCP product (Table 2). A 65\% TCP sub-commercial product is also produced.

There are two sets of screen series at Eshidiya, onefor each of the two ore types (Al and A3); all screens are of the vibrating type and are used for the coarser sizes, i.e. 5,2 and $1 \mathrm{~mm}$. The primary vibrating screens are used to remove the $+5 \mathrm{~mm}$ oversize material from the process as a reject product. These screens operate best when the feed is diluted to about $40 \%$ solids. Capacities of 20 tons $/$ hour $/ \mathrm{m}^{2}$ of screen are the norm at this size and spray water of 25 liter/ton/hour is adequate. Secondary vibrating screens are used to remove the $+1 \mathrm{~mm}$ material from the process as a sub-commercial product. These screens operate best in the range of 25 to $30 \%$ feed solids. Capacities for these screens are reduced to 5 to 10 tons $/$ hour $/ \mathrm{m}^{2}$. Sprays are more important for these screens since this water is used to wash and pull the near-size particles through the mesh openings; about 40 liter/ton/hour is considered adequate. The condition of these screens must be checked regularly, since any holes would pass material $>1 \mathrm{~mm}$, which would be lost during flotation (too coarse to float).

\section{Conclusions}

The chemical analyses of the selected phosphate samples from the Al-Abiad, Al-Hassa and Eshidiya mines show a similar chemical signature, reflecting similar phosphate beneficiation processes. However, in order to enhance the productivity during the process of phosphate flotation, the following should be 
considered. The presence of clay and other fine minerals during conditioning consumes an excessive amount of reagents and hinders recovery and product grade. Properly-sized feed generally results in higher recovery of the coarser fractions in the feed and more selective concentrates from the finer fractions at reduced reagent usage. Water used prior to flotation can be somewhat dirtier than that used directly in flotation but should be relatively free of solids. Water used directly in flotation should be as clean as possible.

\section{R eferences}

Abed, A.M. 1985: On the supposed Precambrian paleosuture along the Dead Sea rift, Jordan. Journal Geological Society London, 142, pp. 27-31.

Barberi, F., G. Capaldi, P. Gasparini, G. Marinelli, R. Santracroce, R. Scandone, M. Tureil 1979: Recent basaltic volcanism of Jordan and its implication on the geodynamic history of the Dead Sea shears zone. - International Symposium, Geodynamic Evol. of the Afro-Arabian Rift System, Rome.

Beall, J.V., P.C. Merritt 1966: Phosphate and potash. - Mining Engineering, 10, pp. 83-89.

Ben-Avraham, Z., M. Grasso 1991: Crustal structure variation and transcurrent faulting at the eastern and western margins of the eastern Mediterranean. - Tectonophysics, 196, pp. 269-277.

Bender, F. 1968: Geological map of Jordan, Amman sheet, scale 1:250000. - Supplement edition in English with minor revisions.

Bender, F. 1974: Geology of Jordan. - Gebrueder Borntraeger, Berlin, $196 \mathrm{p}$

Dewey, J.F., C.C. Pitman, W. Ryan, J. Bonnin 1973: Plate tectonics and the evaluation of Alpine System. - Geol. Soc. Am. Bull., 84, pp. 3137-3180.

Donald, D.C. 1994: Industrial Minerals and Rocks. - Society of Mining, Metallurgy and Exploration Inc., Littleton, Colorado, pp. 735-764.

Elliott, J.C. 1994: Structure and Chemistry of the Apatites and other Calcium Orthophosphates. Elsevier, Amsterdam.

Gieseke, E.W. 1985: Florida Phosphate Rocks. - In: Weiss, N.L. (Ed.): SME Mineral Processing Handbook, Vol. 2, Section 12, New York, SME/AIME.

Hopper, RW. 1976: Phosphates are vital for agriculture and Florida mines one third of the world production. - Engineering and Mining Journal, 5, pp. 79-89.

Jordan Phosphate Mines Co. Ltd. (JPMC) 1999: Open Annual Report, Amman, Jordan.

Jordan Phosphate Mines Co. Ltd. (JPMC) 1991: Open Annual Report, Amman, Jordan.

Lovelock, S. 1984: A review of the tectonics of the northern Middle East Region. - Geol. Mag., 121, pp. 577-587.

Moudgil, B.M., R. Chanchani 1985: Flotation of apatite from dolomite using sodium oleate as the collector. - Minerals and Metallurgical Processing, pp. 13-19.

Quennell, A.M. 1951: The geology and mineral resources of Transjordan. Natural Resources. Journal Geological Society London, 137, pp. 793-805.

Ranney, M.W. (Ed.) 1980: Flotation Agents and Processes: Technology and Applications. - Noyes Data Corp., N ew Jersey.

Sheldon, N. 1964: Palelatitudinal and Paleogeographic Distribution of Phosphorites. - US Geological Survey Professional Paper, 501C, pp. 106-113.

Wills, B.A. 1997: Mineral Processing Technology. - Butterworth Heinemann, Burlington, MA, 6th Edition, $272 \mathrm{p}$.

Zhang, J. 1993: Phosphate Beneficiation Trend of the 90's. - In: El-Shall, H., B.M. Moudgil, R. Wiegel (Eds): Littleton, Colorado, Chapter 40, SME. 